\title{
Recent developments in visible-light photocatalytic degradation of antibiotics
}

\author{
Di Li a, Weidong Shi ${ }^{b}, *$ \\ a Institute for Energy Research, Jiangsu University, Zhenjiang 212013, Jiangsu, China \\ ${ }^{\mathrm{b}}$ School of Chemistry and Chemical Engineering, Jiangsu University, Zhenjiang 212013, Jiangsu, China
}

\section{A R T I C L E I N F O}

Article history:

Received 16 December 2015

Accepted 8 February 2016

Published 5 June 2016

\section{Keywords:}

Antibiotic

Visible-light photocatalyst

Photocatalytic degradation

Doping

Heterojunction

Surface plasmon resonance-enhanced

photocatalysis

\begin{abstract}
A B S T R A C T
With the significant discharge of antibiotic wastewater into the aquatic and terrestrial ecosystems, antibiotic pollution has become a serious problem and presents a hazardous risk to the environment. To address such issues, various investigations on the removal of antibiotics have been undertaken. Photocatalysis has received tremendous attention owing to its great potential in removing antibiotics from aqueous solutions via a green, economic, and effective process. However, such a technology employing traditional photocatalysts suffers from major drawbacks such as light absorption being restricted to the UV spectrum only and fast charge recombination. To overcome these issues, considerable effort has been directed towards the development of advanced visible light-driven photocatalysts. This mini review summarises recent research progress in the state-of-the-art design and fabrication of photocatalysts with visible-light response for photocatalytic degradation of antibiotic wastewater. Such design strategies involve the doping of metal and non-metal into ultraviolet light-driven photocatalysts, development of new semiconductor photocatalysts, construction of heterojunction photocatalysts, and fabrication of surface plasmon resonance-enhanced photocatalytic systems. Additionally, some perspectives on the challenges and future developments in the area of photocatalytic degradation of antibiotics are provided.
\end{abstract}

(C) 2016, Dalian Institute of Chemical Physics, Chinese Academy of Sciences. Published by Elsevier B.V. All rights reserved.

\section{Introduction}

Over recent years, the use of antibiotics worldwide has afforded considerable improvement in the treatment of infectious diseases and agricultural productivity [1]. Antibiotics are a type of antimicrobial used for treating and preventing bacterial infections [2]. Based on the pharmacological properties, the main categories of antibiotics include aminoglycoside, $\beta$-lactam, glycopeptide, macrolide, quinolone, sulphonamide, and tetracycline (TC) [3]. Keiji Fukuda once said that "A world without antibiotics would look very different to the world we live in now". However, with the deliberate release of antibiotics in the environment and lack of effective treatments of antibiotic wastewater, antibiotic pollution poses a serious environmental threat to both the aquatic and terrestrial ecosystems [4].

During the past decade, various strategies have been employed to address the problem of antibiotic wastewater. Biotic elimination processes, such as biodegradation by bacteria and

\footnotetext{
* Corresponding author. Tel/Fax: +86-511-88791800; E-mail: swd1978@ujs. edu.cn

This work was supported by the National Natural Science Foundation of China (21421001, 21276116, 21477050, 21301076, 21303074), Natural Science Foundation of Jiangsu Province (BK20140530, BK20150482), China Postdoctoral Science Foundation (2015M570409), Chinese-German Cooperation Research Project (GZ1091), Program for High-Level Innovative and Entrepreneurial Talents in Jiangsu Province, Program for New Century Excellent Talents in University (NCET-13-0835), Henry Fok Education Foundation (141068), and Six Talents Peak Project in Jiangsu Province (XCL-025).
}

DOI: 10.1016/S1872-2067(15)61054-3 | http://www.sciencedirect.com/science/journal/18722067 | Chin. J. Catal., Vol. 37, No. 6, June 2016 
fungi, and non-biotic processes, including sorption, hydrolysis, oxidation, and reduction, have attracted tremendous attention [5-7]. For example, to investigate the removal of trace antibiotics from wastewater using biodegradation methods, Yang and co-workers studied the adsorption, desorption, and biodegradation characteristics of sulfonamide antibiotics in the presence of activated sludge with and without being subjected to $\mathrm{NaN}_{3}$ biocide [8]. The experimental results showed that the antibiotics were eliminated by sorption and biodegradation by the activated sludge. Gao et al. [9] recently found that graphene oxide (GO) could be used as an adsorbent for the adsorption and removal of TC. Owing to the $\pi-\pi$ interactions and cation $-\pi$ bonding between TC and GO, TC strongly adsorbed on the surface of GO. The adsorption isotherm followed the Langmuir and Temkin models. GO exhibited a better adsorption rate constant $(k=0.065 \mathrm{~g} /(\mathrm{mg} \cdot \mathrm{h}))$ than other studied adsorbents. Liu and co-workers selected four antibiotics i.e., norfloxacin, ofloxacin, roxithromycin, and azithromycin as target antibiotics that were then subjected to disposal treatments of nanofiltration by $\mathrm{UV}_{254}$ photolysis, ozonation, and $\mathrm{UV} / \mathrm{O}_{3}$ process [10]. The $\mathrm{UV} / \mathrm{O}_{3}$ process exhibited the highest efficiency $(>87 \%)$ in eliminating the antibiotics. However, the high cost, low stability, and poor recycling ability limit the application of these methods. Therefore, the development of new methods to address antibiotic pollution remains active and challenging in the area of environment and chemistry.

As one of the most promising methods to treat antibiotic contaminants, photocatalysis has attracted tremendous attention because it is an economic, efficient, and green technology for degrading antibiotics using sunlight and ambient conditions $[11,12]$. Though the basic mechanism for photocatalytic degradation of antibiotics is similar to that of the degradation of organic dyes (discussed in Section 2), most antibiotics are resistant to decomposition owing to their robust molecular structures. Hence, designing and fabricating appropriate photocatalysts with high photocatalytic activities requires considerable research. Among the diverse researched photocatalysts, $\mathrm{TiO}_{2}$ has been the most studied semiconductor for photocatalysis since it was used as a photocatalyst by Fujishima and Honda in 1972 [13]. Though much work has been directed towards enhancing the photocatalytic performance of $\mathrm{TiO}_{2}$ via size and crystal face adjustments and morphology regulation, its application remains limited because of its restricted light absorption capability to the UV light region only [14-17]. The latter corresponds to only about $4 \%$ of the solar light spectrum. Thus, to better exploit the solar light spectrum, it is highly desirable to develop and synthesise advanced photocatalyst systems, with enhanced photocatalytic activities, that can also be activated by visible-light irradiation [18]. In recent years, continuous breakthroughs have been made in the exploration and development of novel visible light-driven photocatalysts, and numerous photocatalytic materials have been synthesised. Some significant discoveries have been reported [19-26].

This mini review focuses on the recent progress in the design and synthesis of visible light-driven photocatalysts towards the photocatalytic degradation of antibiotic wastewater and provides some perspectives on the challenges and future developments in the area of photocatalytic degradation of antibiotics.

\section{Fundamental mechanism of photocatalytic degradation of antibiotics}

The steps involved in the photocatalytic degradation of antibiotics are illustrated in Fig. 1. The entire process includes the following: (I) when light of energy higher than the band gap of the photocatalyst is absorbed by the photocatalyst, excited electrons and holes, with respectively high reducing and oxidising abilities, are generated. Thereafter, the photoinduced electrons and holes separate and migrate to the surface of the photocatalyst; (II) some of the electrons and holes recombine to liberate heat during the migration process; (III) following migration of the electrons to the surface of the photocatalyst, a reductive pathway is initiated, wherein $\mathrm{O}_{2}$ is reduced to $\cdot \mathrm{O}_{2}{ }^{-}$; (IV) conversely, an oxidative pathway is initiated when the holes migrate to the surface of the photocatalyst, and $\cdot \mathrm{OH}$ is generated upon oxidation of $\mathrm{H}_{2} \mathrm{O}$ or the antibiotic molecules. Then, the antibiotic molecules are degraded by the photocatalytic active species $\cdot \mathrm{O}_{2}{ }^{-}$or $\cdot \mathrm{OH}$. All these processes influence the final rate and efficiency of the photocatalytic degradation of antibiotics over the photocatalyst system [27,28]. Therefore, broadening the light absorption spectrum ability of the photocatalysts, enhancing the excited charge separation and migration rate, and preventing the recombination of the excited charges are expected to effectively improve the activities of photocatalysts [29]. Taking these factors into consideration, there are two key methods of developing highly efficient photocatalysts for the photocatalytic degradation of antibiotics: (1) the photocatalyst should have a suitable narrow band gap, which would afford absorption not only of UV light but also visible light, and (2) a suitable separating medium or surface defect state is required, which is capable of trapping the photoexcited electrons or holes to prevent their recombination.

\section{Advanced photocatalysis for photocatalytic degradation of antibiotics}

In recent years, much effort has been directed to designing and fabricating visible light-driven photocatalysts, and diverse advanced photocatalytic materials have been developed for the treatment of antibiotic wastewater [30,31]. Four main strate-

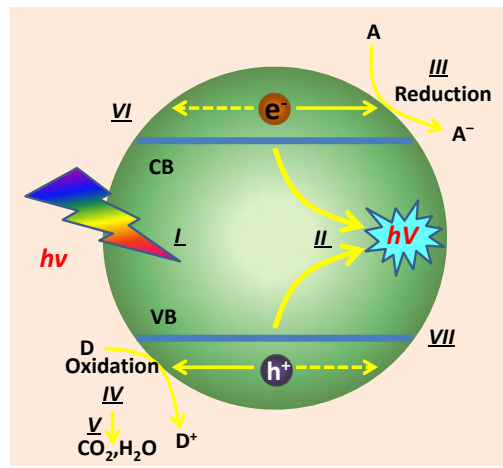

Fig. 1. Basic mechanism of the photocatalytic degradation of antibiotics. 
gies have been employed: (1) doping of UV light-driven photocatalysts with metals and non-metals; (2) development of new visible light-driven semiconductor photocatalysts; (3) design and construction of heterojunction photocatalysts; and (4) design and construction of surface plasmon resonance (SPR)-enhanced photocatalytic systems.

\subsection{Metal- and non-metal-doped photocatalysts}

Doping of metal and non-metal ions can effectively expand the photo-response of photocatalysts to the visible-light spectrum. For instance, when metal ions enter the $\mathrm{TiO}_{2}$ lattice, impurity levels form in $\mathrm{TiO}_{2}$, which will narrow the band gap of $\mathrm{TiO}_{2}$ and enhance the light absorption range. Furthermore, metal ion dopants can influence the photocatalyst photoreactivity by acting as photoinduced charge traps and regulating the recombination rate [32]. However, the presence of excess electrons (or holes) in recombination centres is likely to reduce the amount of photoinduced charges and decrease the photocatalytic activity. Therefore, metal ions should be doped near the surface of the photocatalyst and their concentration should be controlled accordingly to suppress the recombination of electrons and holes. Those processes can be described by the equations below [33]:

Generation of impurity levels

$$
\begin{aligned}
& \mathrm{M}^{n+}+h v \rightarrow \mathrm{M}^{(n+1)+}+\mathrm{e}_{\mathrm{cb}}{ }^{-} \\
& \mathrm{M}^{n+}+h v \rightarrow \mathrm{M}^{(n-1)+}+h_{\mathrm{vb}}{ }^{+}
\end{aligned}
$$

Charge trapping

$$
\begin{aligned}
& \mathrm{M}^{n+}+\mathrm{e}_{\mathrm{cb}}{ }^{-} \rightarrow \mathrm{M}^{(n-1)+} \\
& \mathrm{M}^{n+}+h_{\mathrm{vb}}{ }^{+} \rightarrow \mathrm{M}^{(n+1)+}
\end{aligned}
$$

where $\mathrm{M}$ and $\mathrm{M}^{n+}$ represent the metal and doped metal ion, respectively, and $\mathrm{cb}$ and $\mathrm{vb}$ denote the conduction and valence bands of the photocatalyst, respectively. Zhao et al. [34] synthesised $\mathrm{Bi}_{5} \mathrm{Nb}_{3} \mathrm{O}_{15}$ nanoparticles doped with $\mathrm{Y}^{3+}$ by a combined sol-gel and impregnation method for the first time. The resulting $\mathrm{Y}^{3+}-\mathrm{Bi}_{5} \mathrm{Nb}_{3} \mathrm{O}_{15}$ nanoparticles were then examined towards the treatment of ornidazole wastewater. The nanoparticle photocatalyst exhibited a high photocatalytic activity under visible-light irradiation. Recently, the doping of $\mathrm{SrTiO}_{3}$, which is regarded as one of the most promising photocatalysts for the photocatalytic degradation of antibiotics, has also been examined. The Shi's group synthesised Fe-doped $\mathrm{SrTiO}_{3}$ and Cr-doped $\mathrm{SrTiO}_{3}[35,36]$. Doping metal ions into $\mathrm{SrTiO}_{3}$ led to the formation of new absorption bands in the visible-light region. Furthermore, the band gap of the photocatalysts was reduced. These improved properties enabled the use of the $\mathrm{SrTiO}_{3}$ materials as visible light-driven photocatalysts for TC degradation. The established optimal amounts of dopants (wt\%) Fe and Cr were 3 and $2 \mathrm{wt} \%$, respectively.

When compared with metal ions, non-metal ions are less likely to form recombination centres. Therefore, non-metal ions dopants will not consume the photoinduced charges and are thus more effective for enhancing the photocatalytic activity [32]. Vaiano et al. [37] examined $\mathrm{N}$-doped $\mathrm{TiO}_{2}$ photocatalysts towards the photodegradation of spiramycin under visible-light irradiation. The feasibility of the photocatalytic treatment of spiramycin wastewater over $\mathrm{N}$-doped $\mathrm{TiO}_{2}$ materials under visible-light irradiation was confirmed by total organic carbon analysis. In consideration of the high efficiency and long-term stability, a visible light-mediated C-doped $\mathrm{TiO}_{2}$ photocatalytic system was examined to degrade norfloxacin by Chen and co-workers [38]. The catalyst dosage, solution $\mathrm{pH}$, and initial target compound concentration were key factors that influenced the photocatalytic activity of the $\mathrm{C}-\mathrm{TiO}_{2}$ materials. In another study, Wang et al. [39] fabricated C,N,S-tri-doped $\mathrm{TiO}_{2}$ by a facile, economical, and easy-to-scale-up sol-gel method. The X-ray photoelectron spectroscopy analysis demonstrated that $\mathrm{N}$ and $\mathrm{C}$ were doped in the $\mathrm{TiO}_{2}$ lattice, specifically in the 0 sites, and $\mathrm{S}^{6+}$ substituted in the $\mathrm{Ti}^{4+}$ sites. The C,N,S-tri-doped $\mathrm{TiO}_{2}$ exhibited a higher photocatalytic TC degradation efficiency under visible-light irradiation when compared with non-metal co-doped photocatalyst. The higher photocatalytic efficiency was attributed to higher electron-hole separation efficiency in the tri-doped photocatalyst system.

\subsection{Visible light-driven semiconductor photocatalysts}

Layered bismuth-based complex oxides, such as $\mathrm{BiVO}_{4}$, $\mathrm{Bi}_{2} \mathrm{WO}_{6}, \mathrm{Bi}_{2} \mathrm{MO}_{6}$, and $\mathrm{BiFeO}_{3}$, possess narrow band gaps, fast charge transfer rates, and high stabilities, which make them highly promising candidates for application in the photocatalytic degradation of antibiotics [40-43]. The lone-pair distortion of Bi 6 s orbital in bismuth-based complex oxides may lead to the overlap of $02 p$ and $\mathrm{Bi} 6 s$ orbitals in the valence band, and this overlap is beneficial for the mobility of photoinduced charges, significantly improving the photocatalytic performance [44]. Accordingly, many studies have been devoted to developing Bi-based complex oxide photocatalysts for the photocatalytic degradation of antibiotics. Xiao et al. [45] reported a simple microwave heating method to synthesise hierarchical $\mathrm{Bi}_{24} \mathrm{O}_{31} \mathrm{Br}_{10}$ nanoflakes and systematically investigated their visible-light photocatalytic activity towards the degradation of tetracycline hydrochloride. Owing to the hierarchical structure, $\mathrm{Bi}_{24} \mathrm{O}_{31} \mathrm{Br}_{10}$ nanoflakes featured a high Brunauer-EmmettTeller (BET) surface area and small band gap energy $(2.51 \mathrm{eV})$, which is beneficial for visible-light absorption. Also, the negatively charged surface of $\mathrm{Bi}_{24} \mathrm{O}_{31} \mathrm{Br}_{10}$ nanoflakes promoted the degradation of TC, thereby improving the photocatalytic efficiency. In another study, $\mathrm{BiYO}_{3}$ nanorods were synthesised using a combined hydrothermal and annealing treatment for the first time by $\mathrm{Wu}$ and co-workers [46]. The $\mathrm{BiYO}_{3}$ nanorods photocatalysts, with a narrow band gap of $2.36 \mathrm{eV}$, showed good photocatalytic activity under visible-light irradiation because of fast charge migration and effective electron-hole separation.

Other advanced oxide photocatalysts with visible-light response abilities have been extensively investigated as exemplified. Liu and co-workers successfully fabricated $\mathrm{Zn}_{2} \mathrm{GeO}_{4}$ hollow spheres via a template-driven route using zinc hydroxide carbonate (ZHC) as the template [47]. Upon dissolution of $\mathrm{Zn}^{2+}$ from the surface of the $\mathrm{ZHC}$ spheres, $\mathrm{Zn}_{2} \mathrm{GeO}_{4}$ hollow spheres were generated in situ. The spheres exhibited enhanced photocatalytic activity towards the degradation of antibiotic metronidazole. The results may be ascribed to the high BET surface 
area owing to the hollow structure, which enabled a higher visible light-harvesting efficiency and generated effective reaction sites. The Shi's group synthesised $\mathrm{MgFe}_{2} \mathrm{O}_{4}$ nanofibres by direct annealing of electrospun precursor fibres, followed by a heat treatment process [48]. The nanofibres were examined towards the photocatalytic degradation of TC under visible light. The possible mechanism is illustrated in Fig. 2. The unique rod-in-tube structure afforded excellent photocatalytic activity towards the degradation of TC; the structure enhanced light utilisation by light refraction and reflection. Additionally, the authors demonstrated the potential of rhombohedral $\mathrm{In}_{2} \mathrm{O}_{3}$ with well-defined, three-dimensional, flower-like porous nanostructures as a visible-light photocatalyst for the photocatalytic degradation of TC [49]. When compared with bulk $\mathrm{In}_{2} \mathrm{O}_{3}$, the three-dimensional, flower-like porous rhombohedral $\mathrm{In}_{2} \mathrm{O}_{3}$ displayed a higher photocatalytic performance, which was attributed to the nature of the crystal phase and high charge separation efficiency.

\subsection{Heterojunction photocatalysts}

Recently, heterojunction photocatalytic systems, which constitute a combination of two semiconductors with matching energy band gaps, have attracted increasing attention because such a structure is an efficient way to separate the photoinduced charges, thereby enhancing the photocatalytic performance [50]. Heterojunction architectures are classified into three main groups denoted as type I, type II, and type III [51]. Of the three photocatalyst systems, type II heterojunction is believed to show the most potential in realising the highest photocatalytic efficiency as the configuration can effectively prevent the recombination of electrons and holes. The typical mechanism for photogenerated charge transfer in type II heterojunction photocatalyst systems is illustrated in Fig. 3. As observed, the photoexcited electrons can migrate from semiconductor I to semiconductor II in a type II heterojunction owing to the more negative conduction band position of semiconductor I. Simultaneously, because of the more positive valence band of semiconductor II, photoexcited holes can migrate in the opposite direction to that of electrons, leading to complete effective charge separation [51]. Furthermore, type II hetero-

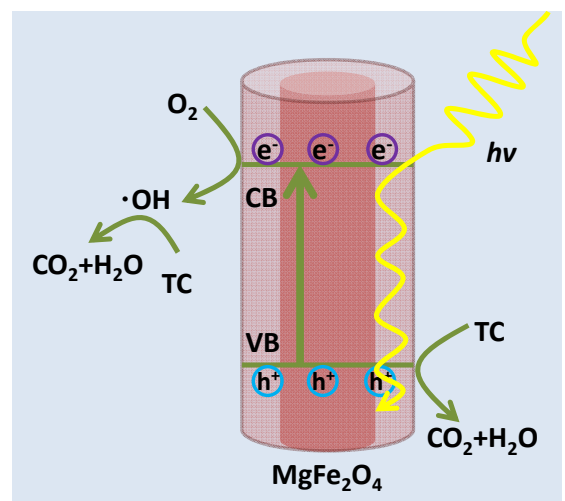

Fig. 2. Possible mechanism for the photocatalytic degradation of TC over $\mathrm{MgFe}_{2} \mathrm{O}_{4}$ under visible-light irradiation. Reprinted with permission from Ref. [48]. Copyright 2016, The Royal Society of Chemistry.

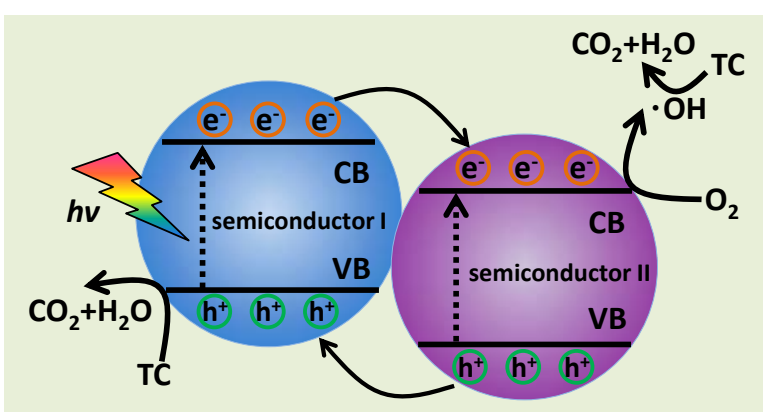

Fig. 3. Schematic of the mechanism of photogenerated charge transfer in a type II heterojunction photocatalyst system.

junction is conducive to regulating the range of light absorption. To date, numerous studies have focused on the development of type II heterojunction photocatalyst systems, and many advanced heterojunction photocatalysts with enhanced photocatalytic antibiotic degradation efficiency under visible-light irradiation have been synthesised [52].

Since the pioneering study on graphitic carbon nitride (g- $\mathrm{C}_{3} \mathrm{~N}_{4}$ ) by Wang et al. [53-56], g- $\mathrm{C}_{3} \mathrm{~N}_{4}$-based photocatalysts have attracted increasing interest for application in the field of visible-light photocatalysis owing to their unique electronic band structure and high chemical stability. Hong et al. [57] synthesised a $\mathrm{V}_{2} \mathrm{O}_{5} / g-\mathrm{C}_{3} \mathrm{~N}_{4}$ heterojunction photocatalyst system via a facile in situ growth strategy, and the photocatalytic activities of the photocatalysts were investigated towards the photocatalytic degradation of TC under visible-light irradiation. The $\mathrm{V}_{2} \mathrm{O}_{5} / \mathrm{g}-\mathrm{C}_{3} \mathrm{~N}_{4}$ heterojunction photocatalysts showed significantly enhanced photocatalytic performance when compared with pure g- $\mathrm{C}_{3} \mathrm{~N}_{4}$ and $\mathrm{V}_{2} \mathrm{O}_{5}$. The heterojunction system can not only improve the photoinduced charge separation, but also exhibits strong redox ability, resulting in efficient degradation of TC. Furthermore, combining UV light-driven photocatalysts with $\mathrm{g}-\mathrm{C}_{3} \mathrm{~N}_{4}$ to form a heterojunction structure is a useful method to develop visible light-driven photocatalysts for the degradation of antibiotics. For instance, the possible growth strategy of $\mathrm{V}_{2} \mathrm{O}_{5} / \mathrm{g}-\mathrm{C}_{3} \mathrm{~N}_{4}$ heterojunction photocatalysts is illustrated in Fig. 4. In another study, Song et al. [58] reported an ordinary solid-phase calcination method for the fabrication of g- $\mathrm{C}_{3} \mathrm{~N}_{4} / \mathrm{NaNbO}_{3}$ composite. The g- $\mathrm{C}_{3} \mathrm{~N}_{4} / \mathrm{NaNbO}_{3}$ photocatalyst displayed an excellent degradation rate, which was 2.7 times higher than that obtained for pristine g- $\mathrm{C}_{3} \mathrm{~N}_{4}$.

Other examples of heterojunction photocatalysts include the deposition of PbS-CdS onto clinoptilolite nanoparticles. The later photocatalyst system was successfully prepared by Azimi and co-workers and displayed good photocatalytic activity towards the degradation of a mixed aqueous solution of TC and cephalexin [59]. The existence of the PbS-CdS heterojunction was important for realising efficient electron transfer and charge separation. The same results were also obtained by Ren and co-workers who fabricated $\mathrm{NiFe}_{2} \mathrm{O}_{4} / \mathrm{Bi}_{2} \mathrm{O}_{3}$ heterostructures by a combined hydrothermal and microwave-assisted method [60]. When compared with pure $\mathrm{NiFe}_{2} \mathrm{O}_{4}$ and $\mathrm{Bi}_{2} \mathrm{O}_{3}$, the $\mathrm{NiFe}_{2} \mathrm{O}_{4} / \mathrm{Bi}_{2} \mathrm{O}_{3}$ heterostructures exhibited twice higher photocatalytic activities. 


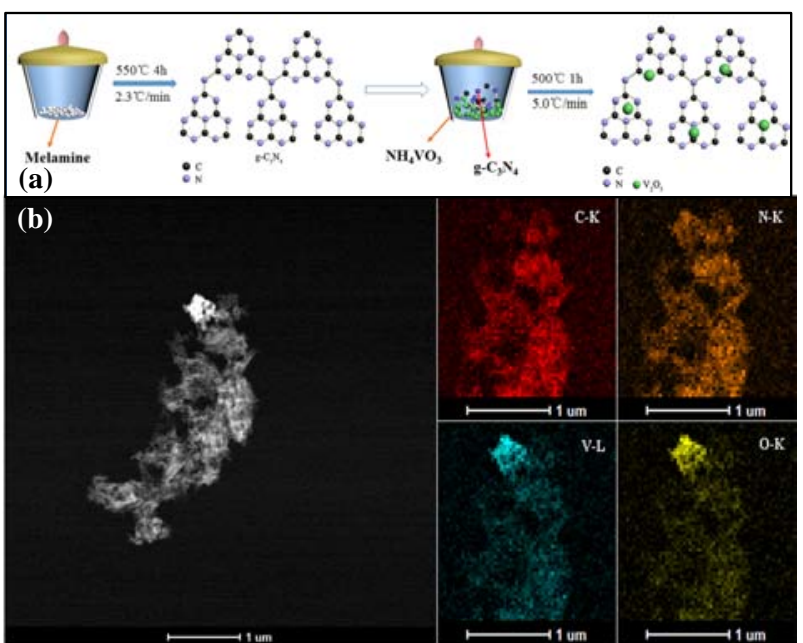

Fig. 4. (a) Schematic of the in situ growth strategy of $\mathrm{V}_{2} \mathrm{O}_{5} / g-\mathrm{C}_{3} \mathrm{~N}_{4}$ heterojunction photocatalysts. (b) High-angle annular dark field scanning transmission electron microscopy images of $\mathrm{V}_{2} \mathrm{O}_{5} / \mathrm{g}-\mathrm{C}_{3} \mathrm{~N}_{4}\left(\mathrm{~V}_{2} \mathrm{O}_{5} / \mathrm{g}-\mathrm{C}_{3} \mathrm{~N}_{4}\right.$ $=1.0 \%$ ) sample with maps of $\mathrm{C}-\mathrm{K}, \mathrm{N}-\mathrm{K}, \mathrm{V}-\mathrm{L}$, and $\mathrm{O}-\mathrm{K}$. Reprinted with permission from Ref. [57]. Copyright 2015, Elsevier.

\subsection{SPR-enhanced photocatalysts}

For the past few years, SPR-enhanced photocatalysts, involving metal nanoparticles that exhibit strong plasmon resonance (e.g., $\mathrm{Au}, \mathrm{Ag}$ ), have emerged and been considered as a new type of visible-light photocatalyst with improved photocatalytic performance [61]. Plasmons are generated upon collective oscillation of free charges in conductors. Particularly, surface plasmons are oscillations confined to the surfaces of conductors and exhibit strong interactions with light. When the real part of the dielectric function is zero, resonance absorption occurs, and strong electric fields at the surface of the nanoparticles are generated when the metal nanoparticles are irradiated by light under their plasmon frequency [62]. Fig. 5 schematically illustrates the possible mechanism of photogenerated charge transfer in a plasmonic photocatalyst system. Upon light irradiation, if the frequency of the photons matches the natural frequency of surface oscillating electrons and is enough to prevent the restoring force of positive nuclei, the valence electrons

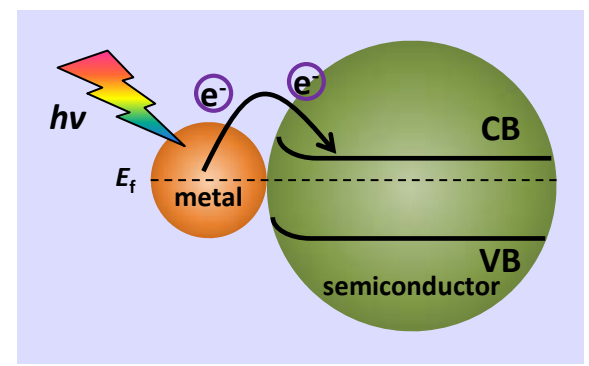

Fig. 5. Schematic of mechanism of photogenerated charge transfer in a plasmonic photocatalyst system.

of metal nanoparticles are generated. When such metal nanoparticles combine with other semiconductors, electrons migrate to the semiconductor material, consequently enhancing the light absorption and photocatalytic performance of the nearby semiconductor photocatalyst [63]. Using the SPR technology, visible light-driven photocatalysts can be developed from native UV light-based photocatalysts.

For example, Wang et al. [64] synthesised $\mathrm{Ag} / \mathrm{Ag}_{3} \mathrm{PO}_{4} /$ active carbon composite photocatalysts using a simple coupling-deposition method. Owing to the plasmonic effects of the $\mathrm{Ag}$ nanoparticles, which were loaded on the surface of $\mathrm{Ag}_{3} \mathrm{PO}_{4}$, the composite photocatalysts exhibited high visible-light absorption activity. Therefore, the $\mathrm{Ag} / \mathrm{Ag}_{3} \mathrm{PO}_{4} /$ active carbon composite photocatalysts showed considerably improved photocatalytic activities towards the degradation of TC. The Shi's group conducted in-depth research on the synthesis of SPR-enhanced photocatalysts towards the photocatalytic degradation of antibiotics. As exemplified, Ag nanoparticles were considered. Binary composite photocatalysts $\mathrm{Ag} / \mathrm{Bi}_{3.84} \mathrm{~W}_{0.16} \mathrm{O}_{6.24}$ nanooctahedron, $\mathrm{Ag} / \mathrm{K}_{2} \mathrm{Ta}_{2} \mathrm{O}_{6}$, and $\mathrm{Ag} / \mathrm{Bi}_{3} \mathrm{TaO}_{7}$ and ternary composite photocatalyst $\mathrm{Ag} / \mathrm{AgBr} / \mathrm{AgIn}\left(\mathrm{MoO}_{4}\right)_{2}$ were successfully prepared [65-68]. In these photocatalysis systems, Ag nanoparticles served as both an SPR initiator and a medium for electron transfer. Fig. 6 shows a possible mechanism of the photocatalytic reaction involving the $\mathrm{Ag} / \mathrm{AgBr} / \mathrm{AgIn}\left(\mathrm{MoO}_{4}\right)_{2}$ photocatalyst system. Au nanoparticles have also been used to fabricate plasmonic photocatalysts. An $\mathrm{Au} / \mathrm{Pt} / \mathrm{g}-\mathrm{C}_{3} \mathrm{~N}_{4}$ plasmonic photocatalyst with enhanced photocatalytic activity to-
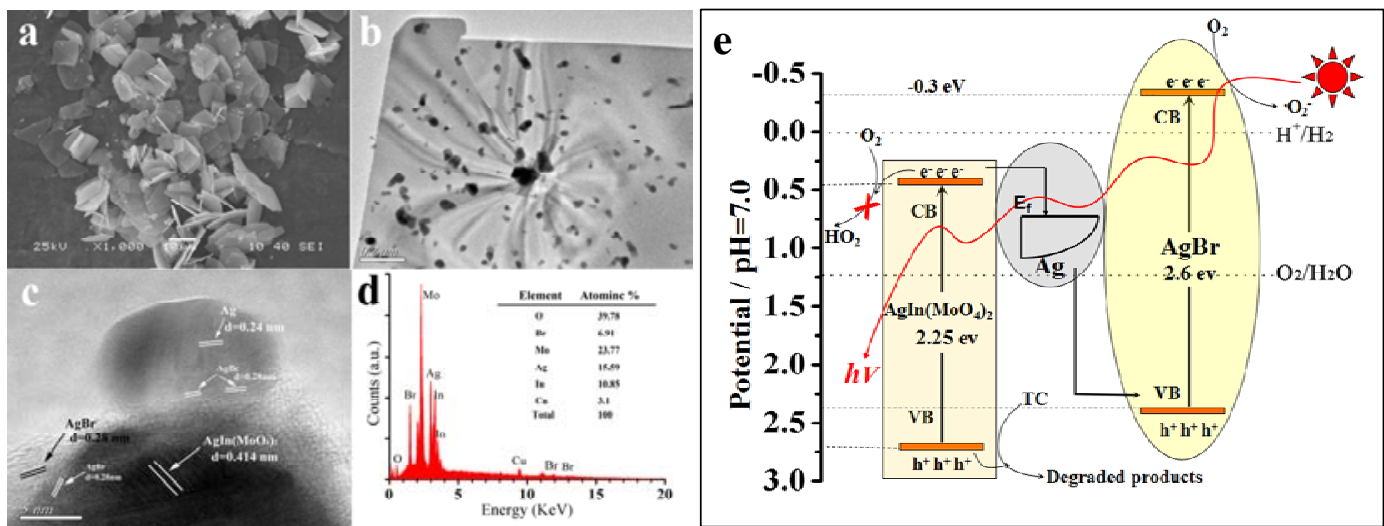

Fig. 6. (a) Field-emission scanning electron microscopy image of AgIn $\left(\mathrm{MoO}_{4}\right)_{2}$ nanosheets. (b) Transmission electron microscopy, (c) high-resolution transmission electron microscopy, and (d) energy-dispersive X-ray spectrum of Ag/AgBr/AgIn( $\left.\mathrm{MoO}_{4}\right)_{2}$. (e) Schematic of mechanism of the photocatalytic reaction occurring on the $\mathrm{Ag} / \mathrm{AgBr} / \mathrm{AgIn}\left(\mathrm{MoO}_{4}\right)_{2}$ photocatalyst system. Reprinted with permission from Ref. [68]. Copyright 2015, Elsevier. 
wards antibiotic degradation was fabricated by Xue and co-workers. The degradation rate was 3.4 times higher than that obtained for pristine $\mathrm{g}-\mathrm{C}_{3} \mathrm{~N}_{4}$ [69]. The authors proposed that the high photocatalytic performance was due to the SPR effect of the Au nanoparticles and the electron-sink function of the Pt nanoparticles. The above-discussed studies demonstrate that the SPR effect can effectively improve the light absorption range and photogenerated electron transfer rate of photocatalysts and enhance the photocatalytic performance towards the degradation of antibiotics. The studies provide far-sighted insight into the design and development of plasmonic photocatalysts for enhancing visible light-driven photocatalytic activity in the area of antibiotic degradation.

\section{Conclusions and outlook}

In this mini review, four strategies for fabricating visible light-driven photocatalysts for the photocatalytic degradation of antibiotics have been discussed, including: (1) doping of metal and non-metal into UV light-driven photocatalysts; (2) development of new semiconductor photocatalysts; (3) construction of heterojunction photocatalysts; and (4) construction of SPR-enhanced photocatalytic systems. These methods afforded visible light-driven photocatalysts with enhanced photocatalytic activity by either narrowing the band gap of the photocatalyst or improving charge separation. The recently achieved progress in this field indicates that the application of visible light-driven photocatalysts is a potential method to treat antibiotic wastewater. The large-scale production of photocatalysts is necessary to realise the commercial application of photocatalysis in treating antibiotic waste. Therefore, the development of simple and effective methods for large-scale preparation is key to photocatalyst application.

To date, improvements in the photocatalytic performance of photocatalysts under visible-light irradiation remain challenging. Fast charge transfer and efficient charge separation are critical to enhance photocatalytic activity. Two-dimensional graphene nanostructures have attracted increasing research interests owing to their superior specific surface area and electrical conductivity. Construction of visible light-driven photocatalytic systems using graphene materials can effectively ac- celerate the migration of photogenerated electrons and holes and promote photoinduced charge separation to attain high photocatalytic efficiency. Some studies on the application of graphene-based photocatalysts in antibiotic degradation have been initiated [70,71], and over the next few years, graphene-based photocatalysts are expected to be developed as robust materials for antibiotic wastewater treatment.

\section{References}

[1] D. W. Graham, S. Olivares-Rieumont, C. W. Knapp, L. Lima, D. Werner, E. Bowen, Environ. Sci. Technol., 2011, 45, 418-424.

[2] D. J. Dire, M. Coppola, D. A. Dwyer, J. J. Lorette, J. L. Karr, Acad. Emerg. Med., 1995, 2, 4-10.

[3] K. Kümmerer, Chemosphere, 2009, 75, 417-434.

[4] Q. Sui, X. Q. Cao, S. G. Lu, W. T. Zhao, Z. F. Qiu, G. Yu, Emerg. Contam., 2015, 1, 14-24.

[5] N. Dorival-García, A. Zafra-Gómez, A. Navalón, J. González-López, E. Hontoria, J. L. Vílchez, J. Environ. Manage, 2013, 120, 75-83.

[6] A. Białk-Bielińska, S. Stolte, M. Matzke, A. Fabiańska, J. Maszkowska, M. Kołodziejska, B. Liberek, P. Stepnowski, J. Kumirska, J. Hazard. Mater., 2012, 221-222, 264-274.

[7] J. Jeong, W. H. Song, W. J. Cooper, J. Jung, J. Greaves, Chemosphere, 2010, 78, 533-540.

[8] S. F. Yang, C. F. Lin, A. Y. C. Lin, P. K. A. Hong, Water Res., 2011, 45, 3389-3397.

[9] Y. Gao, Y. Li, L. Zhang, H. Huang, J. J. Hu, S. M. Shah, X. G. Su, J. Colloid Interf. Sci., 2012, 368, 540-546.

[10] P. X. Liu, H. M. Zhang, Y. J. Feng, F. L. Yang, J. P. Zhang, Chem. Eng. J., 2014, 240, 211-220.

[11] S. S. Boxi, S. Paria, RSC Adv., 2015, 5, 37657-37668.

[12] H. S. Kushwaha, A. Halder, D. Jain, R. Vaish, J. Electron. Mater., 2015, 44, 4334-4342.

[13] A. Fujishima, K. Honda, Nature, 1972, 238, 37-38.

[14] N. Satoh, T. Nakashima, K. Kamikura, K. Yamamoto, Nat. Nanotechnol., 2008, 3, 106-111.

[15] H. G. Yang, C. H. Sun, S. Z. Qiao, J. Zou, G. Liu, S. C. Smith, H. M. Cheng, G. Q. Lu, Nature, 2008, 453, 638-641.

[16] T. R. Gordon, M. Cargnello, T. Paik, F. Mangolini, R. T. Weber, P. Fornasiero, C. B. Murray, J. Am. Chem. Soc., 2012, 134, 6751-6761.

[17] Y. J. Xie, X. Zhang, P. J. Ma, Z. J. Wu, L. Y. Piao, Nano Res., 2015, 8, 2092-2101.

[18] M. Pelaez, N. T. Nolan, S. C. Pillai, M. K. Seery, P. Falaras, A. G. Kontos, P. S. M. Dunlop, J. W. J. Hamilton, J. A. Byrne, K. O’Shea, M. H.

\section{Graphical Abstract}

Chin. J. Catal., 2016, 37: 792-799 doi: 10.1016/S1872-2067(15)61054-3

\section{Recent developments in visible-light photocatalytic degradation of antibiotics}

Di Li, Weidong Shi*

Jiangsu University

This minireview summarises recent state-of-the-art research progress in the design and fabrication of visible light-driven photocatalysts for the degradation of antibiotic wastewater and provides perspectives on challenges and future developments in the area.

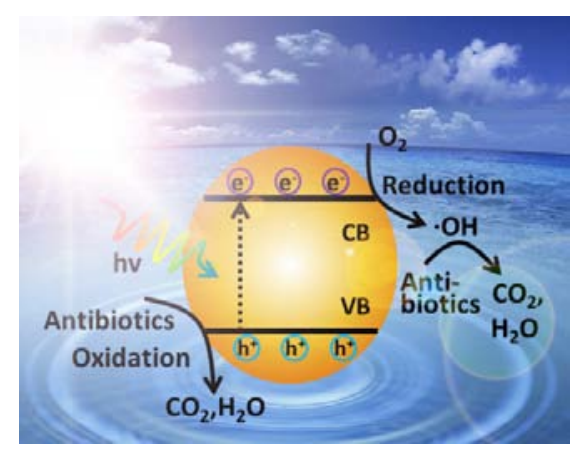


Entezari, D. D. Dionysiou, Appl. Catal. B, 2012, 125, 331-349.

[19] Z. G. Xiong, X. S. Zhao, J. Am. Chem. Soc., 2012, 134, 5754-5757.

[20] R. Asahi, T. Morikawa, T. Ohwaki, K. Aoki, Y. Taga, Science, 2001, 293, 269-271.

[21] G. Liu, Y. N. Zhao, C. H. Sun, F. Li, G. Q. Lu, H. M. Cheng, Angew. Chem. Int. Ed., 2008, 120, 4592-4596.

[22] Y. Peng, L. Shang, Y. T. Cao, Q. Wang, Y. F. Zhao, C. Zhou, T. Bian, L. Z. Wu, C. H. Tung, T. R. Zhang, Appl. Surf. Sci., 2015, 358, 485-490.

[23] Y. Peng, L. Shang, Y. T. Cao, G. I. N. Waterhouse, C. Zhou, T. Bian, L. Z. Wu, C. H. Tung, T. R. Zhang, Chem. Commun., 2015, 51, 12556-12559.

[24] J. T. Li, S. K. Cushing, P. Zheng, T. Senty, F. K. Meng, A. D. Bristow, A. Manivannan, N. Q. Wu, J. Am. Chem. Soc., 2014, 136, 8438-8449.

[25] T. Bian, L. Shang, H. J. Yu, M. T. Perez, L. Z. Wu, C. H. Tung, Z. H. Nie, Z. Y. Tang, T. R. Zhang, Adv. Mater., 2014, 26, 5613-5618.

[26] C. Zhou, Y. F. Zhao, L. Shang, Y. H. Cao, L. Z. Wu, C. H. Tung, T. R. Zhang, Chem. Commun., 2014, 50, 9554-9556.

[27] H. L. Wang, L. S. Zhang, Z. G. Chen, J. Q. Hu, S. J. Li, Z. H. Wang, J. S. Liu, X. C. Wang, Chem. Soc. Rev., 2014, 43, 5234-5244.

[28] M. R. Hoffmann, S. T. Martin, W. Choi, D. W. Bahnemannt, Chem. Rev., 1995, 95, 69-96.

[29] V. Keller, P. Bernhardt, F. Garin, J. Catal., 2003, 215, 129-138.

[30] J. Di, J. X. Xia, Y. P. Ge, H. P. Li, H. Y. Ji, H. Xu, Q. Zhang, H. M. Li, M. N. Li, Appl. Catal. B, 2015, 168-169, 51-61.

[31] E. Topkaya, M. Konyar, H. C. Yatmaz, K. Öztürk, J. Colloid Interf. Sci., 2014, 430, 6-11.

[32] M. Ni, M. K. H. Leung, D. Y. C. Leung, K. Sumathy, Renew. Sust. Energ. Rev., 2007, 11, 401-425.

[33] W. Choi, A. Termin, M. R. Hoffmann, J. Phys. Chem., 1994, 98, 13669-13679.

[34] J. Zhao, B. H. Yao, Q. He, T. Zhang, J. Hazard. Mater., 2012, 229-230, 151-158.

[35] P. Li, C. B. Liu, G. L. Wu, Y. Heng, S. Lin, A. Ren, K. H. Lv, L. S. Xiao, W. D. Shi, RSC Adv., 2014, 4, 47615-47624.

[36] F. P. Cai, Y. B. Tang, F. Y. Chen, Y. Yan, W. D. Shi, RSC Adv., 2015, 5 , 21290-21296.

[37] V. Vaiano, O. Sacco, D. Sannino, P. Ciambelli, Chem. Eng. J., 2015 261, 3-8.

[38] M. J. Chen, W. Chu, J. Hazard. Mater., 2012, 219-220, 183-189.

[39] P. H. Wang, P. S. Yap, T. T. Lim, Appl. Catal. A, 2011, 399, 252-261.

[40] M. J. Chen, W. Chu, Ind. Eng. Chem. Res., 2012, 51, 4887-4893.

[41] D. Sánchez-Martínez, D. B. Hernández-Uresti, L. M. Torres-Martinez, S. Mejia-Rosales, Res. Chem. Intermed., 2015, 41, 8839-8854.

[42] D. He, Y. B. Sun, S. B. Li, J. W. Feng, J. Chem. Technol. Biotechnol, 2015, 90, 2249-2256.

[43] Z. H. Xue, T. Wang, B. D. Chen, T. Malkoske, S. L. Yu, Y. L. Tang Materials, 2015, 8, 6360-6378.

[44] S. M. Sun, W. Z. Wang, RSC Adv., 2014, 4, 47136-47152.

[45] X. Xiao, R. P. Hu, C. Liu, C. L. Xing, X. X. Zuo, J. M. Nan, L. S. Wang, Chem. Eng. J., 2013, 225, 790-797.

[46] M. M. Wu, D. B. Xu, B. F. Luo, H. Q. Shen, C. Wang, W. D. Shi, Mater
Lett., 2015, 161, 45-48.

[47] J. Liu, G. K. Zhang, J. C. Yu, Y. D. Guo, Dalton Trans., 2013, 42, 5092-5099.

[48] J. H. Jiang, W. Q. Fan, X. Zhang, H. Y. Bai, Y. Liu, S. Huang, B. D. Mao, S. L. Yuan, C. B. Liu, W. D. Shi, New J. Chem., 2016, 40, 538-544.

[49] M. M. Wu, C. Wang, Y. Zhao, L. S. Xiao, C. Zhang, X. Q. Yu, B. F. Luo, B. Hu, W. Q. Fan, W. D. Shi, CrystEngComm, 2015, 17, 2336-2345.

[50] F. T. Li, Q. Wang, X. J. Wang, B. Li, Y. J. Hao, R. H. Liu, D. S. Zhao, Appl. Catal. B, 2014, 150-151, 574-584.

[51] S. J. A. Moniz, S. A. Shevlin, D. J. Martin, Z. X. Guo, J. W. Tang, Energy Environ. Sci., 2015, 8, 731-759.

[52] Y. Feng, X. Yan, C. B. Liu, Y. Z. Hong, L. Zhu, M. J. Zhou, W. D. Shi, Appl. Surf. Sci., 2015, 353, 87-94.

[53] X. C. Wang, K. Maeda, A. Thomas, K. Takanabe, G. Xin, J. M. Carlsson, K. Domen, M. Antonietti, Nat. Mater., 2009, 8, 76-80.

[54] D. L. Jiang, J. Li, C. S. Xing, Z. Y. Zhang, S. C. Meng, M. Chen, ACS Appl. Mater. Interfaces, 2015, 7, 19234-19242.

[55] Z. Y. Zhang, D. L. Jiang, D. Li, M. Q. He, M. Chen, Appl. Catal. B, 2016, 183, 113-123.

[56] F. F. Shi, L. L. Chen, M. Chen, D. L. Jiang, Chem. Commun., 2015, 51, 17144-17147.

[57] Y. Z. Hong, Y. H. Jiang, C. S. Li, W. Q. Fan, X. Yan, M. Yan, W. D. Shi, Appl. Catal. B, 2016, 180, 663-673.

[58] C. J. Song, M. S. Fan, B. Hu, T. J. Chen, L. P. Wang, W. D. Shi, CrystEngComm, 2015, 17, 4575-4583.

[59] S. Azimi, A. Nezamzadeh-Ejhieh, J. Mol. Cata.l A, 2015, 408, 152-160.

[60] A. Ren, C. B. Liu, Y. Z. Hong, W. D. Shi, S. Lin, P. Li, Chem. Eng. J., 2014, 258, 301-308.

[61] F. Dong, Z. W. Zhao, Y. J. Sun, Y. X. Zhang, S. Yan, Z. B. Wu, Environ. Sci. Technol., 2015, 49, 12432-12440.

[62] S. Linic, P. Christopher, D. B. Ingram, Nat. Mater., 2011, 10, 911-921.

[63] W. B. Hou, S. B. Cronin, Adv. Funct. Mater., 2013, 23, 1612-1619.

[64] H. Q. Wang, Z. F. Ye, C. Liu, J. Z. Li, M. J. Zhou, Q. F. Guan, P. Lv, P. W. Huo, Y. S. Yan, Appl. Surf. Sci., 2015, 353, 391-399.

[65] X. Y. Li, L. P. Wang, D. B. Xu, J. C. Lin, P. Li, S. Lin, W. D. Shi, CrystEngComm, 2015, 17, 2421-2428.

[66] D. B. Xu, K. L. Liu, W. D. Shi, M. Chen, B. F. Luo, L. S. Xiao, W. Gu, Ceram. Int., 2015, 41, 4444-4451.

[67] B. F. Luo, D. B. Xu, D. Li, G. L. Wu, M. M. Wu, W. D. Shi, M. Chen, ACS Appl. Mater. Interfaces, 2015, 7, 17061-17069.

[68] X. Yan, X. Y. Wang, W. Gu, M. M. Wu, Y. Yan, B. Hu, G. B. Che, D. L. Han, J. H. Yang, W. Q. Fan, W. D. Shi, Appl. Catal. B, 2015, 164, 297-304.

[69] J. J. Xue, S. S. Ma, Y. M. Zhou, Z. W. Zhang, M. He, ACS Appl. Mater. Interfaces, 2015, 7, 9630-9637.

[70] Y. F. Tang, X. L. Liu, C. C. Ma, M. J. Zhou, P. W. Huo, L. B. Yu, J. M. Pan, W. D. Shi, Y. S. Yan, New J. Chem., 2015, 39, 5150-5160.

[71] J. J. Xue, S. S. Ma, Y. M. Zhou, Q. L. Wang, RSC Adv., 2015, 5, 88249-88257.

\title{
可见光光催化降解抗生素研究进展
}

\author{
李 娣 ${ }^{\mathrm{a}}$, 施伟东 ${ }^{\mathrm{b}, *}$ \\ a江苏大学能源研究院, 江苏镇江 212013 \\ b江苏大学化学化工学院, 江苏镇江 212013
}

摘要: 随着抗生素废水在水体和陆地生态系统的肆意排放, 抗生素污染已成为当今世界重要的环境问题. 由于抗生素废水 具有生物毒性大、含有抑菌物质等特点, 传统的物理吸附法、生物处理法在处理这类难降解有毒有机废水, 尤其是含残留 
微量抗生素的废水时效果较差. 为了解决抗生素废水所引起的环境危机, 人们尝试了许多方法. 近年来, 光催化技术作为 一种适用范围广、反应速率快、氧化能力强、无污染或少污染的处理抗生素废水的方法受到人们广泛关注. 半导体材料 在太阳光照射下, 可产生具有较强氧化作用的羟基或超氧自由基, 从而起到降解抗生素分子的作用. 然而, 传统的光催化 处理抗生素废水光催化剂主要局限于 $\mathrm{TiO}_{2}$ 半导体, 它存在太阳光谱吸收范围窄、光生电荷复合率高等问题, 严重制约其工 业化应用. 因此, 人们一直致力于开发高效、稳定的可见光响应型光催化剂. 本文根据光催化技术的基本原理, 综述了目前 几种基于不同策略设计开发可见光光催化降解抗生素废水的新型光催化剂的方法.

离子掺杂改性宽带隙半导体是开发高效可见光光催化剂的常用方法. 通过过渡金属离子或非金属离子掺杂改性, 可以 使传统的 $\mathrm{TiO}_{2}$ 和 $\mathrm{SrTiO}_{3}$ 等紫外光催化剂吸收带边发生红移, 响应可见光, 从而显著提高可见光下光催化剂降解抗生素的效 率. 然而必须注意的是, 掺杂的金属离子本身会成为电子-空穴复合点位, 因此, 过量的掺杂金属或非金属离子可能会降低 其光催化活性. 考虑到单一半导体材料在光催化反应中存在的光生载流子容易复合、可见光利用率低等问题, 构建异质结 构复合光催化体系, 通过不同半导体之间的协同作用, 促进光生电荷的分离与转移, 是获得高效光催化体系的重要策略之 一. 典型的 II 型异质结光催化剂, 当不同的半导体紧密接触时, 由于异质结两侧能带等性质的不同会形成空间电势差, 从 而有利于光生载流子的分离, 光催化效率提高. 作为一种复合光催化体系, 表面等离子体共振增强型光催化体系近年来引 起了国内外学者的广泛关注. Ag, Au和Pd 金属纳米粒子在吸收光后其表面发生等离共振, 随后等离子体发生衰减, 把聚集 的能量转移到半导体材料的导带. 这个过程产生的高能电子 (热电子), 逃离贵金属纳米粒子而被与其接触的半导体收集, 从而形成金属-半导体肖特基接触. 形成的肖特基结可以显著提高光催化的光生电荷分离效率, 从而提高光催化降解抗生 素活性.

目前, 与传统物化法/生化法相比, 光催化技术用于处理抗生素废水具有十分明显的技术优势, 在水处理方面有着很好 的应用前景. 针对目前光催化体系存在的光生载流子容易复合的巨大挑战, 今后, 构筑高效复合光催化体系 (例如石墨烯 基二维复合光催化剂在光生电荷分离、太阳光利用率等方面已展现出较好的综合性能) 将成为高效光催化降解抗生素催化 剂研发的重要方向之一.

关键词: 抗生素; 可见光催化剂; 光催化降解; 掺杂; 异质结; 表面等离子体增强型光催化剂

收稿日期: 2015-12-16. 接受日期: 2016-02-08. 出版日期: 2016-06-05.

*通讯联系人. 电话/传真: (0511)88791800; 电子信箱: swd1978@ujs. edu.cn

基金来源：国家自然科学基金(21421001, 21276116, 21477050, 21301076, 21303074); 江苏省自然科学基金(BK20140530, BK20150482); 中国博士后科学基金(2015M570409); 中德合作研究项目(GZ1091); 江苏省高层次创新创业人才项目; 新世纪优 秀人才支持计划(NCET-13-0835); 霍英东教育基金(141068); 江苏省六大人才高峰计划(XCL-025).

本文的英文电子版由Elsevier出版社在ScienceDirect上出版(http://www.sciencedirect.com/science/journal/18722067). 